\title{
Effects of hydrogen sulfide on the expression of alkaline phosphatase, osteocalcin and collagen type $I$ in human periodontal ligament cells induced by tension force stimulation
}

\author{
JING QIN and YONGMEI HUA \\ Department of Orthodontics, School and Hospital of Stomatology, Tongji University, \\ Shanghai Engineering Research Center of Tooth Restoration and Regeneration, Shanghai 200072, P.R. China
}

Received September 6, 2015; Accepted August 2, 2016

DOI: $10.3892 / \mathrm{mmr} .2016 .5680$

\begin{abstract}
Periodontal ligament cells (PDLCs) are important in homeostasis and remodeling in the mechanically-stimulated periodontium. The aim of the present study was to investigate the effects of hydrogen sulfide $\left(\mathrm{H}_{2} \mathrm{~S}\right)$ on periodontal tissue remodeling by examining the mRNA and protein expression levels of alkaline phosphatase (ALP), osteocalcin (OCN) and collagen type I (COL-1) in human (h)PDLCs induced by tension force application. Cultured hPDLCs were treated with $\mathrm{H}_{2} \mathrm{~S}$ for $24 \mathrm{~h}$, followed by application of a tension force for 1,3 and $6 \mathrm{~h}$. Cell proliferation and apoptosis were determined using a Cell Counting Kit 8 assay and flow cytometric analysis, respectively. The mRNA expression levels of ALP, OCN and COL-1 were quantified using reverse transcription-quantitative polymerase chain reaction analysis, and western blot analysis was used to detect the protein levels of ALP, OCN and COL-1. The results demonstrated that the mRNA and protein expression levels of ALP, OCN and COL-1 increased with $\mathrm{H}_{2} \mathrm{~S}$ treatment in a concentration-dependent manner, which was enhanced by the application of tension force in a relatively short period of time. These findings suggested that $\mathrm{H}_{2} \mathrm{~S}$ may be important in periodontal tissue remodeling during orthodontic tooth movement via increasing hPDLC differentiation, tissue mineralization, bone formation and collagen synthesis.
\end{abstract}

\section{Introduction}

The periodontium is composed of gingival tissue, periodontal ligament, alveolar bone and cementum. During orthodontic tooth movement, periodontal ligament cells (PDLCs) are directly

Correspondence to: Dr Yongmei Hua, Department of Orthodontics, School and Hospital of Stomatology, Tongji University, Shanghai Engineering Research Center of Tooth Restoration and Regeneration, 399 Middle Yanchang Road, Zhabei, Shanghai 200072, P.R. China E-mail: yongmeihua@tongji.edu.cn

Key words: hydrogen sulfide, human periodontal ligament cells, tension force, alkaline phosphatase, osteocalcin, collagen type I subject to mechanical stress, and are critical in regulating the processes of periodontal tissue repair and remodeling (1). Previously, several studies have shown that orthodontic tooth movement is regulated by PDLCs via modulation of the activity of alkaline phosphatase (ALP), production of osetocalcin (OCN) and synthesis of collagen type I (COL-1). In addition, the biological characteristics of PDLCs can be altered under the action of mechanical force (2-5). It is generally accepted that ALP is involved in the process of calcification in various mineralizing tissues (6). OCN is considered to be a marker of bone formation $(7,8)$. Collagen fibers are the predominant component of the periodontal ligament extracellular matrix (ECM), and collagen types I and III are important in periodontal tissue remodeling (9). Therefore, the synthesis and degradation of ECM are key processes in the regulation of bone remodeling (10).

Hydrogen sulfide $\left(\mathrm{H}_{2} \mathrm{~S}\right)$ is an endogenous gaseous signaling molecule, which has been traditionally classified as a toxic gas (11). In previous years, it was reported that low concentrations of $\mathrm{H}_{2} \mathrm{~S}$ have anti-inflammatory, cytoprotective and chemopreventative potential (12), and have shown anticancer effects $(13,14) . \mathrm{H}_{2} \mathrm{~S}$ is synthesized endogenously from L-cysteine in mammals by at least two pyridoxal-5'-phosphate-dependent enzymes, cystathionine- $\gamma$-lyase and cystathionine $\beta$-synthase, in various organs $(15,16)$. This molecule can permeate the cellular membrane without the assistance of a specific transporter. There are limited reports regarding with the effects of $\mathrm{H}_{2} \mathrm{~S}$ on the biological activity of human PDLCs (hPDLCs), particularly during mechanical stress. Our previous results showed that $\mathrm{H}_{2} \mathrm{~S}$ upregulated the expression ratio of OPG/receptor activator of nuclear factor- $\kappa \mathrm{B}$ ligand (RANKL) in hPDLCs, with the maximum effect being observed at $0.5 \mathrm{mM}$, and tension force enhanced the effect of $\mathrm{H}_{2} \mathrm{~S}$ on the expression of OPG/RANKL (17). The present study, investigated the effect of $\mathrm{H}_{2} \mathrm{~S}$ on the expression levels of ALP, OCN and COL-1 in hPDLCs with and without tension force in order to further understand the effects of $\mathrm{H}_{2} \mathrm{~S}$ on periodontal tissue remodeling.

\section{Materials and methods}

Cell isolation and culture. The hPDLCs were obtained from 21 patients (10 male and 11 female) aged between 12 
and 16 years who required premolar extraction during the course of orthodontic treatment between August 2014 and October 2014 at Affiliated Stomatology Hospital of Tongji University (Shanghai, China). All patients signed informed consent and the study was approved by the Ethics Committee (2013-NSFC002) of Tongji University (Shanghai, China). The teeth, which were absent of inflammation, were immediately placed into a tube containing 1\% Dulbecco's modified Eagle's medium (DMEM; Hyclone; GE Healthcare Life Sciences, Logan, UT, USA), $100 \mathrm{U} / \mathrm{ml}$ penicillin and $100 \mathrm{U} / \mathrm{ml}$ streptomycin. The cells were scraped from the middle third of the root and maintained in DMEM supplemented with $15 \%$ charcoal-stripped serum (Gibco; Thermo Fisher Scientific, Inc., Waltham, MA, USA), $100 \mathrm{U} / \mathrm{ml}$ penicillin and $100 \mathrm{mg} / \mathrm{ml}$ streptomycin at $37^{\circ} \mathrm{C}$ in a $5 \% \mathrm{CO}_{2}$ incubator, with replacement of the medium every 2 days. On reaching confluence, the cells were detached with $0.25 \%$ trypsin without EDTA and subcultured at a 1:3 ratio (18). In the subsequent experiments, cells between the third and eighth passages were used.

Cell viability assay. To determine cell viability, the hPDLCs were seeded into two 96-well plates with a cell density of $5 \times 10^{3}$ cells per well. Each treatment group was evaluated in triplicate. Sodium hydrosulfide (NaHS), as an exogenous donor (19), has been used to examine various biological activities of $\mathrm{H}_{2} \mathrm{~S}$. In the present study, NaHS (Aladdin, Shanghai, China) was dissolved in phosphate-buffered saline (PBS) and diluted into four concentrations $(0.01,0.05,0.1$ and $0.5 \mathrm{mM})$ with DMEM supplemented with $2 \%$ charcoal-stripped serum. The cells were then treated with $\mathrm{H}_{2} \mathrm{~S}(0.01-0.5 \mathrm{mM})$ for $1-5$ days and incubated at $37^{\circ} \mathrm{C}$ in $5 \% \mathrm{CO}_{2}$. A Cell Counting Kit 8 (CCK 8) was then used to determine the viability of the cells. The optical density (OD) values of the media were measured at $\lambda=450 \mathrm{~nm}$ using a microplate reader (Infinite $^{\mathrm{TM}}$ 200; Tecan Austria GmbH, Grödig, Austria).

Flow cytometric analysis. The hPDLCs $\left(1 \times 10^{6}\right.$ cells $\left./ \mathrm{ml}\right)$ were seeded in six-well plates and treated with $\mathrm{H}_{2} \mathrm{~S}(0.01,0.05,0.1$ and $0.5 \mathrm{mM}$ ) for $1-5$ days at $37^{\circ} \mathrm{C}$ in $5 \% \mathrm{CO}_{2}$. An Annexin $\mathrm{V}$-fluorescein isothiocyanate (FITC) kit (BioVison, Inc., Mountain View, CA, USA) was used to assess the apoptosis of cells following treatment with $\mathrm{H}_{2} \mathrm{~S}$ for different durations.

Tension force stimulation. The cells $\left(1 \times 10^{6}\right.$ cells $\left./ \mathrm{ml}\right)$ were seeded into four flexible plates and pre-treated with $\mathrm{H}_{2} \mathrm{~S}$ $(0,0.01,0.05,0.1$ and $0.5 \mathrm{mM})$ in DMEM containing $2 \%$ charcoal-stripped serum for $24 \mathrm{~h}$ at $37^{\circ} \mathrm{C}$ in $5 \% \mathrm{CO}_{2}$. The four flexible plates were subjected to a wave of $5 \%$ elongation, $0.5 \mathrm{~Hz}(2 \mathrm{sec})(20)$ for 1,3 and $6 \mathrm{~h}$ every time. The cells were collected for western blot and reverse transcription-quantitative polymerase chain reaction (RT-qPCR) analyses.

RT-qPCR analysis. Total cellular mRNA was obtained using TRIzol reagent (Invitrogen; Thermo Fisher Scientific, Inc.) according to the manufacturer's protocol. Complementary DNA was synthesized using a PrimeScript 1st Strand cDNA Synthesis kit (Takara Bio, Inc., Tokyo, Japan). The qPCR was performed using a SYBR Premix Ex Taq II (Tli RNase H Plus) kit (Takara Bio, Inc.) in an ABI Prism 7500 Detection System (Applied Biosystems; Thermo Fisher Scientific, Inc.).
The primer sequences are listed in Table I. The thermocycling conditions were as follows: $37^{\circ} \mathrm{C}$ for $15 \mathrm{~min}$ and $85^{\circ} \mathrm{C}$ for $5 \mathrm{sec}$ (for the reverse transcription); followed by 40 cycles of $95^{\circ} \mathrm{C}$ for $5 \mathrm{sec}$ and $60^{\circ} \mathrm{C}$ for $34 \mathrm{sec}$. Relative fold changes were calculated using the $2^{-\Delta \Delta \mathrm{Cq}}$ method (21) and standard curves were produced. The $\mathrm{Cq}$ values of the samples were normalized to the appropriate endogenous housekeeping gene, GAPDH. Each measurement was performed in triplicate.

Western blot analysis. The cells were lysed using radioimmunoprecipitation assay buffer (Beyotime Institute of Biotechnology, Haimen, China) and stored at $-80^{\circ} \mathrm{C}$. The cell lysates were separated on 10\% (ALP and COL-1) and $15 \%$ (OCN) SDS-polyacrylamide electrophoresis gels and transferred onto polyvinylidene difluoride membranes (EMD Millipore, Billerica, MA, USA) using a semi-dry transfer cell (Tannon Science \& Technology Co., Ltd., Shanghai, China). The membranes were blocked for $1 \mathrm{~h}$ in 5\% dry milk, rinsed and incubated with rabbit polyclonal anti-ALP antibody (cat. no. ab95462), rabbit monoclonal anti-OCN antibody (cat. no. ab133612), rabbit monoclonal anti-COL 1 antibody (cat. no. ab138492; all obtained from Abcam, Cambridge, MA, USA) at 1:1,000 dilutions in Tris-buffered saline (TBS) overnight at $4^{\circ} \mathrm{C}$. The primary antibodies were then removed by washing the membranes three times in TBS. The primary antibodies were labeled by incubation with $0.1 \mathrm{mg} / \mathrm{ml}$ horseradish peroxidase-labeled goat anti-rabbit secondary antibodies $(1: 2,000$; cat. no. KGAA35; Nanjing KeyGen Biotech Co., Ltd., Nanjing, China) at room temperature for $1 \mathrm{~h}$. Following three washes in TBS, the antibody-bound proteins were detected using an enhanced chemiluminescence system (EMD Millipore).

Statistical analysis. All data in the present study are presented as the mean \pm standard deviation from three independent experiments. Data was analyzed using Student's $t$-test with SAS 8.2 (SAS Institute, Cary, NC, USA). P<0.05 was considered to indicate a statistically significant difference.

\section{Results}

Effect of $\mathrm{H}_{2} \mathrm{~S}$ on cell proliferation. The cells were treated with different concentrations of $\mathrm{H}_{2} \mathrm{~S}$ for 1-5 days. $\mathrm{H}_{2} \mathrm{~S}$ had no significant effect on cell proliferation when the hPDLCs were treated for 3 days. However, $\mathrm{H}_{2} \mathrm{~S}$ reduced the proliferation of the hPDLCs in a concentration-dependent manner following 4 and 5 days of incubation (Fig. 1).

Effect of $\mathrm{H}_{2} \mathrm{~S}$ on cell apoptosis. No effects of $\mathrm{H}_{2} \mathrm{~S}$ on cell apoptosis were detected using flow cytometry when the cells were treated up to 4 days. However, $\mathrm{H}_{2} \mathrm{~S}$ significantly induced apoptosis at the concentration of $0.5 \mathrm{mM}$ following 5 days of treatment (Fig. 2A-E).

Effect of $\mathrm{H}_{2} \mathrm{~S}$ on mRNA expression levels of ALP, OCN and $C O L-1$. Data on the mRNA expression levels were obtained using RT-qPCR analysis, and the results showed that $\mathrm{H}_{2} \mathrm{~S}$ significantly upregulated the mRNA expression levels of ALP, OCN and COL-1 in the hPDLCs at the concentration of $0.5 \mathrm{mM}$ (Fig. 3A-C). Treatment with 0.1 and $0.5 \mathrm{mM} \mathrm{H}_{2} \mathrm{~S}$ increased the mRNA expression levels of ALP and COL-1 
Table I. Primer sequences for ALP, OCN, COL-1 and GAPDH.

\begin{tabular}{llc}
\hline Gene & \multicolumn{1}{c}{$\begin{array}{c}\text { Primer sequence } \\
\left(5^{\prime}-3^{\prime}\right)\end{array}$} & $\begin{array}{c}\text { Length } \\
(\mathrm{bp})\end{array}$ \\
\hline ALP & F: CTACACGGTCCTCCTATAC & 19 \\
& R: CTCGCTCTCGGTAACATC & 18 \\
OCN & F: CAGAGTCCAGCAAAGGTG & 18 \\
& R: CCAGCCATTGATACAGGTA & 19 \\
COL-1 & F: GCTGTCTTATGGCTATGATGAGAA & 24 \\
& R: GACCACGAGGACCAGAGG & 18 \\
GAPDH & F: AGAAGGCTGGGGCTCATTTG & 20 \\
& R: AGGGGCCATCCACAGTCTTC & 20 \\
\hline
\end{tabular}

F, forward; R, reverse; ALP, alkaline phosphatase; OCN, osteocalcin; COL-1, collagen type I.

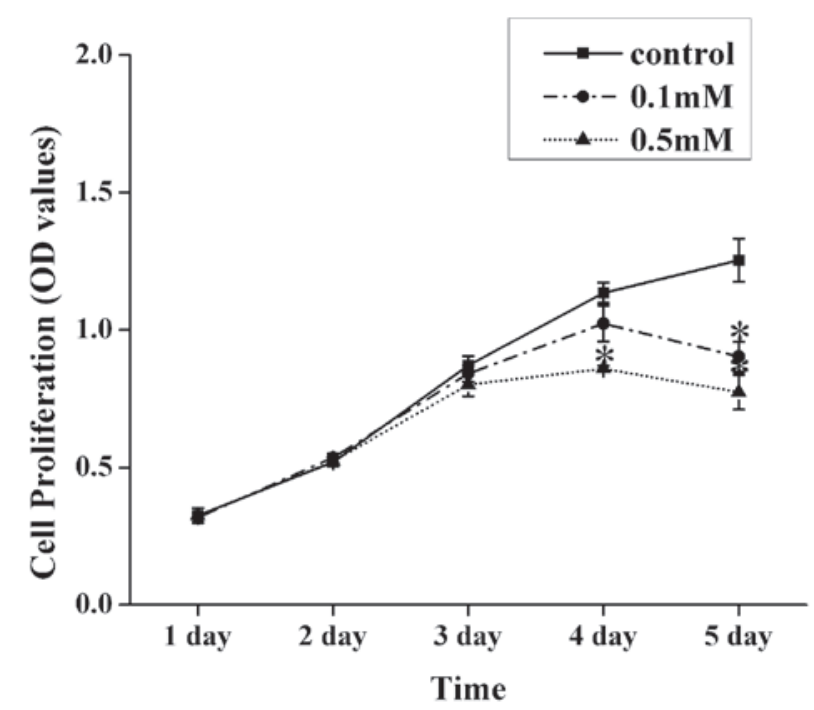

Figure 1. Effects of $\mathrm{H}_{2} \mathrm{~S}$ on cell proliferation. hPDLCs were treated with $\mathrm{H}_{2} \mathrm{~S}(0.1$ and $0.5 \mathrm{mM})$, OD values were measured using a Cell-Counting Kit 8 assay. The viability of the hPDLCs was significantly reduced following treatment of the cells with $0.1 \mathrm{mM} \mathrm{H}_{2} \mathrm{~S}$ for 5 days, and $0.5 \mathrm{mM}$ $\mathrm{H}_{2} \mathrm{~S}$ for 4 and 5 days. Data are presented as the mean \pm standard deviation. ${ }^{*} \mathrm{P}<0.05$, vs. control. hPDLCs, human periodontal ligament cells; OD, optical density; $\mathrm{H}_{2} \mathrm{~S}$, hydrogen sulfide.

induced by $1 \mathrm{~h}$ tension force stimulation (Fig. 3A and C). Treatment with $0.05-0.5 \mathrm{mM} \mathrm{H}_{2} \mathrm{~S}$ upregulated the mRNA expression levels of ALP and COL-1 following tension force application for 3 and $6 \mathrm{~h}$ (Fig. 3A and C). The mRNA expression levels of OCN induced by tension force stimulation for 1 , 3 and 6 h significantly increased following pretreatment with $0.05,0.1$ and $0.5 \mathrm{mM} \mathrm{H}_{2} \mathrm{~S}$ (Fig. 3B).

Effect of $\mathrm{H}_{2} \mathrm{~S}$ on protein expression levels of $A L P, O C N$ and $C O L-1$. To investigate the role of $\mathrm{H}_{2} \mathrm{~S}$ in hPDLCs, the protein expression levels of ALP, OCN and COL-1 were determined using western blot analysis following $\mathrm{H}_{2} \mathrm{~S}$ pretreatment with or without subsequent tension force application (Fig.4 A-D). The results showed that treatment with $0.05-0.5 \mathrm{mM} \mathrm{H}_{2} \mathrm{~S}$ significantly upregulated the protein expression levels of ALP, OCN and COL-1 (Fig. 4E-G). Treatment with 0.01-0.5 mM $\mathrm{H}_{2} \mathrm{~S}$ significantly upregulated the protein expression levels of ALP and OCN in the cells subjected to 1 and $3 \mathrm{~h}$ of tension force application, and the protein expression levels of ALP and OCN induced by $6 \mathrm{~h}$ tension force application significantly increased in the cells pre-exposed to $\mathrm{H}_{2} \mathrm{~S} 0.05-0.5 \mathrm{mM}$; Fig. $4 \mathrm{E}$ and F). Treatment with $0.01-0.5 \mathrm{mM} \mathrm{H}_{2} \mathrm{~S}$ significantly upregulated the protein expression of COL-1 in the cells induced by tension force application for $1 \mathrm{~h}$, and treatment with $0.05-0.5 \mathrm{mM} \mathrm{H}_{2} \mathrm{~S}$ significantly upregulated the protein expression of COL-1 in the cells subjected to tension force for 3 and $6 \mathrm{~h}$. However, protein expression levels of OCN and COL-1 induced by $3 \mathrm{~h}$ of tension force was more marked, compared with those subjected to 1 and $6 \mathrm{~h}$ tension force application following pretreatment with $0.5 \mathrm{mM} \mathrm{H}_{2} \mathrm{~S}$ (Fig. 4F and G).

\section{Discussion}

$\mathrm{H}_{2} \mathrm{~S}$ has been recognized as a gasotransmitter, which has multiple physiological and pathophysiological functions in various mammalian systems $(22,23)$. It has been reported that $\mathrm{H}_{2} \mathrm{~S}$ has potential anti-inflammatory, anti-apoptotic, anticancer and neuroprotective effects $(24,25)$. Previous studies have shown that the exogenous donor of NaHS significantly protects PC12 cells against formaldehyde-induced cytotoxicity and apoptosis through attenuating the accumulation of reactive oxygen species (ROS), upregulating levels of B cell lymphoma-2 (Bcl-2) and downregulating the expression of Bcl-2-associated $\mathrm{X}$ protein $(26,27)$. In the present study, cytotoxicity was observed in response to $\mathrm{H}_{2} \mathrm{~S}$ at a high concentration (Fig. 2). A high concentration of $\mathrm{H}_{2} \mathrm{~S}$ may increase ROS formation and mitochondrial depolarization (28), decreasing the concentration of oxygen and leading to hypoxia and cell death. By contrast, low concentrations of $\mathrm{H}_{2} \mathrm{~S}$ were protective and relatively safe to hPDLCs, suggesting $<0.5 \mathrm{mM} \mathrm{H}_{2} \mathrm{~S}$ is useful in hPDLCs.

hPDLCs produce ECM components, including collagen, which build up the periodontal ligament to secure attachment of the root cementum to the surrounding alveolar bone and is important in the restoration of mineralized tissue (29-31). In the present study, hPDLCs were isolated and characterized for their mesenchymal origin, with confirmation of their fibroblast-like morphology, as in our previous report (17). hPDLCs are capable of producing ALP, OCN and COL-1, suggesting osteoblastand fibroblast-like features, which is consistent with previous studies $(32,33)$. hPDLCs can differentiate into either osteoblasts or cementoblasts in response to mechanical force (34-38). In the present study, in order to investigate the effect of $\mathrm{H}_{2} \mathrm{~S}$ on hPDLCs during orthodontic tooth movement, an appropriate tension force was applied to the hPDLCs following $\mathrm{H}_{2} \mathrm{~S}$ treatment. As mentioned previously, our previous study demonstrated that $\mathrm{H}_{2} \mathrm{~S}$ had a regulatory role within the periodontal remodeling process by promoting osteogenic differentiation via upregulating the expression ratio of OPG/RANKL in the hPDLCs. This promoting effect of $\mathrm{H}_{2} \mathrm{~S}$ on OPG/RANKL was enhanced by tension force application (17). In the present study, it was observed that $\mathrm{H}_{2} \mathrm{~S}$ upregulated the expression levels of ALP, OCN and COL-1 in a concentration-dependent manner, and pre-treatment with $\mathrm{H}_{2} \mathrm{~S}$ enhanced the expression levels of ALP, OCN and COL-1 induced by tension force application. 
A

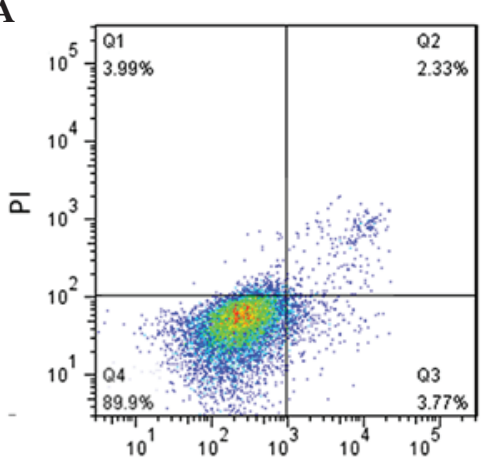

C

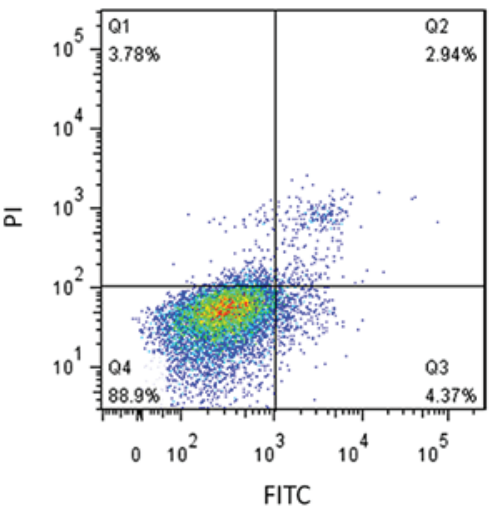

B

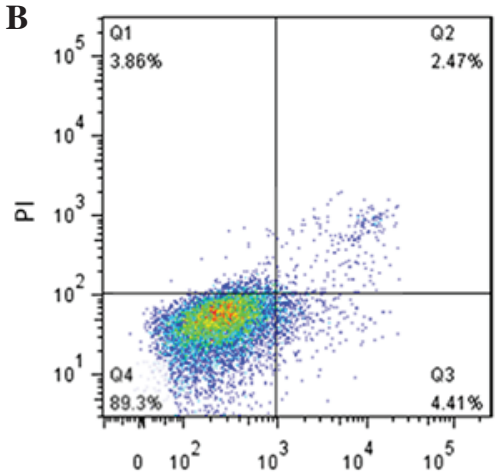

D
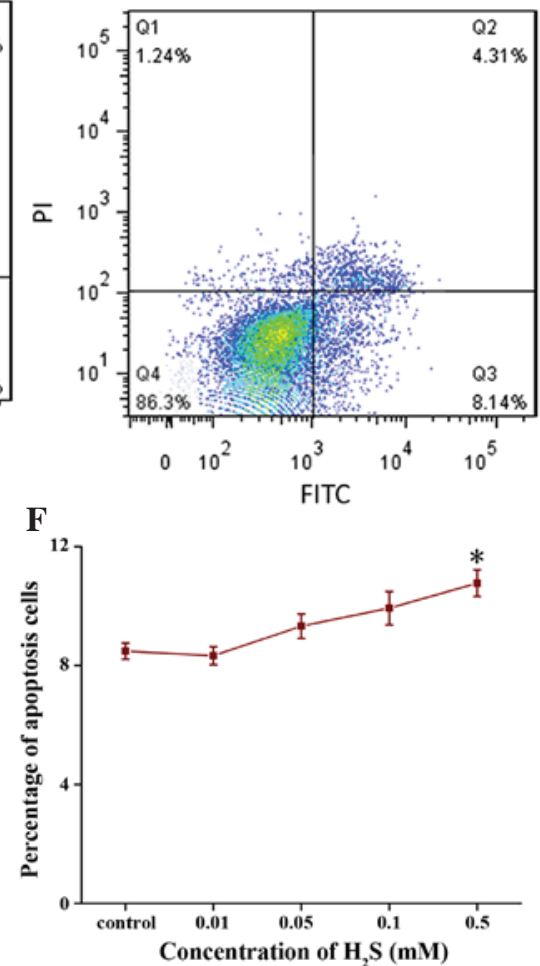

Figure 2. Effects of $\mathrm{H}_{2} \mathrm{~S}$ on hPDLC apoptosis. Cells were treated with $\mathrm{H}_{2} \mathrm{~S}(0.01-0.5 \mathrm{mM})$ for 5 days and flow cytometry was used to detect cell apoptosis. Representative flow cytometry results are shown for the (A) control group and the (B) 0.01 , (C) 0.05 , (D) 0.1 and (E) $0.5 \mathrm{mM} \mathrm{H}_{2} \mathrm{~S}$ groups. Q2 and Q4 represent early and late apoptosis, respectively. (F) Apoptotic cells are expressed as a percentage of the total cell number. A significant increase in apoptosis was observed in the $0.5 \mathrm{mM} \mathrm{H}_{2} \mathrm{~S}$ group. " $\mathrm{P}<0.05$, vs. control. hPDLCs, human periodontal ligament cells; $\mathrm{H}_{2} \mathrm{~S}$, hydrogen sulfide; FITC, fluorescein isothiocyanate; PI, propidium iodide.
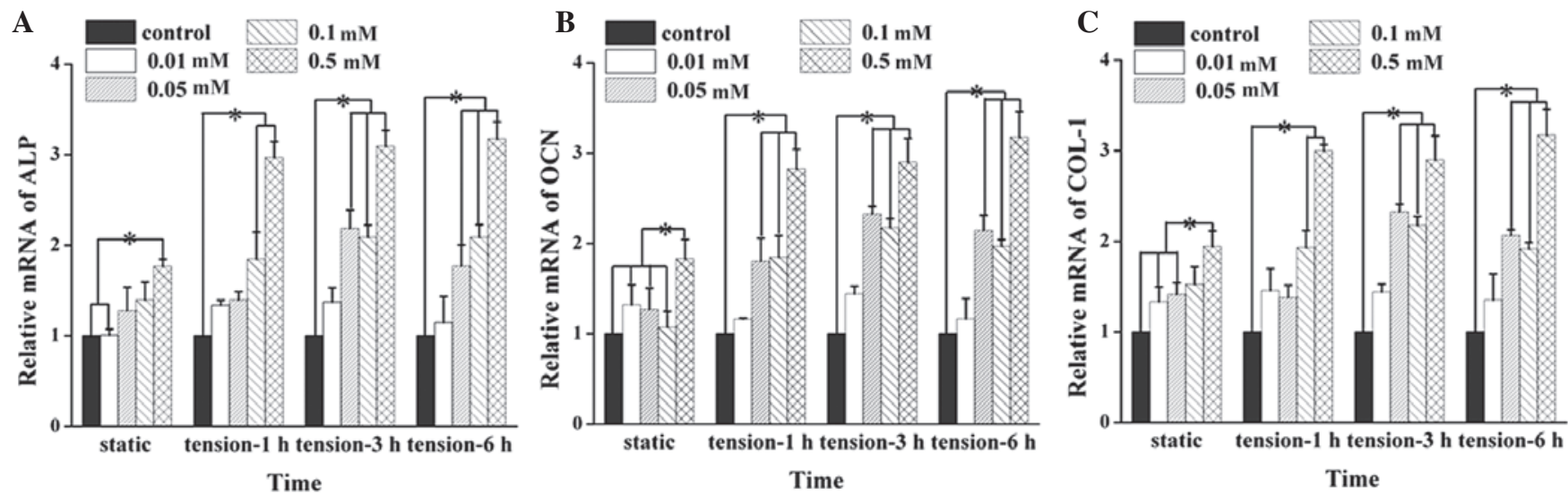

Figure 3. mRNA expression levels of ALP, OCN and COL-1 following $\mathrm{H}_{2} \mathrm{~S}$ treatment. Treatment with $0.5 \mathrm{mM}_{2} \mathrm{~S}$ significantly upregulated the mRNA expression of (A) ALP, (B) OCN and (C) COL-1 in the cells. Treatment with 0.1 and $0.5 \mathrm{mM} \mathrm{H}_{2} \mathrm{~S}$ enhanced mRNA expression of ALP and COL-1 following $1 \mathrm{~h}$ mechanical tension stimulation. (B) Pretreatment with $\mathrm{H}_{2} \mathrm{~S}(0.05-0.5 \mathrm{mM})$ significantly upregulated the mRNA expression of OCN induced by tension force (1, 3 and $6 \mathrm{~h}$ ). Treatment with $0.05-0.5 \mathrm{mM} \mathrm{H}_{2} \mathrm{~S}$ significantly upregulated the mRNA expression of ALP and COL-1 following 3 and $6 \mathrm{~h}$ tension force. Data are expressed as the mean \pm standard deviation ("P<0.05). $\mathrm{H}_{2} \mathrm{~S}$, hydrogen sulfide; ALP, alkaline phosphatase; OCN, osteocalcin; COL-1, collagen type I. 
A

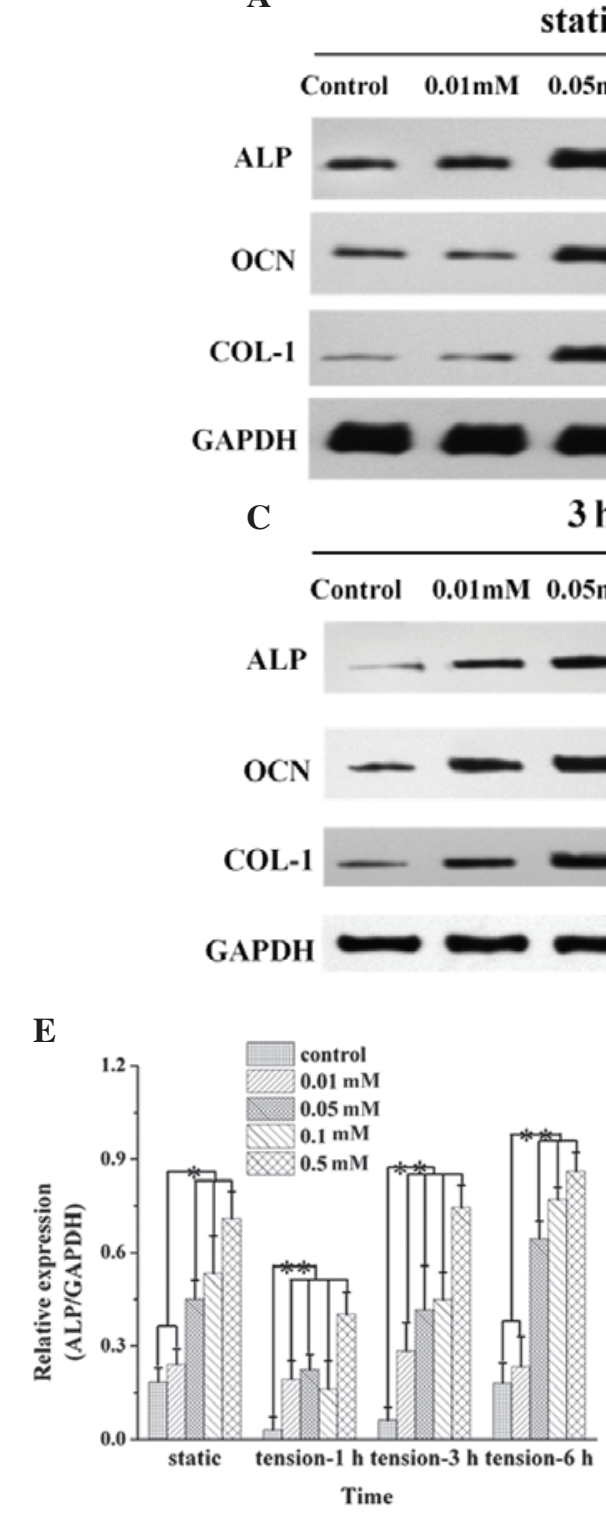

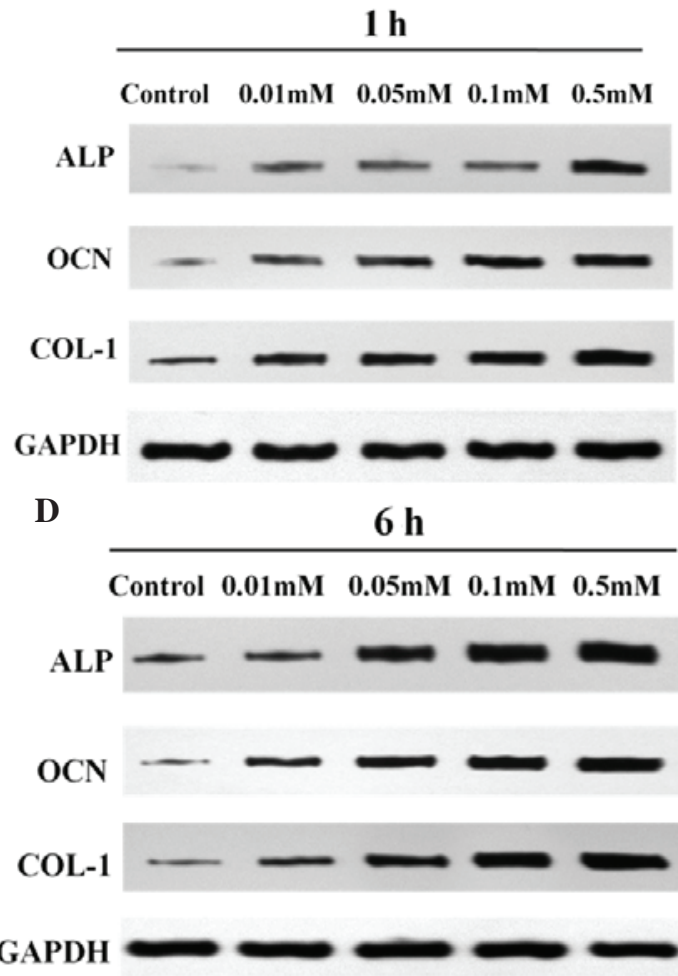
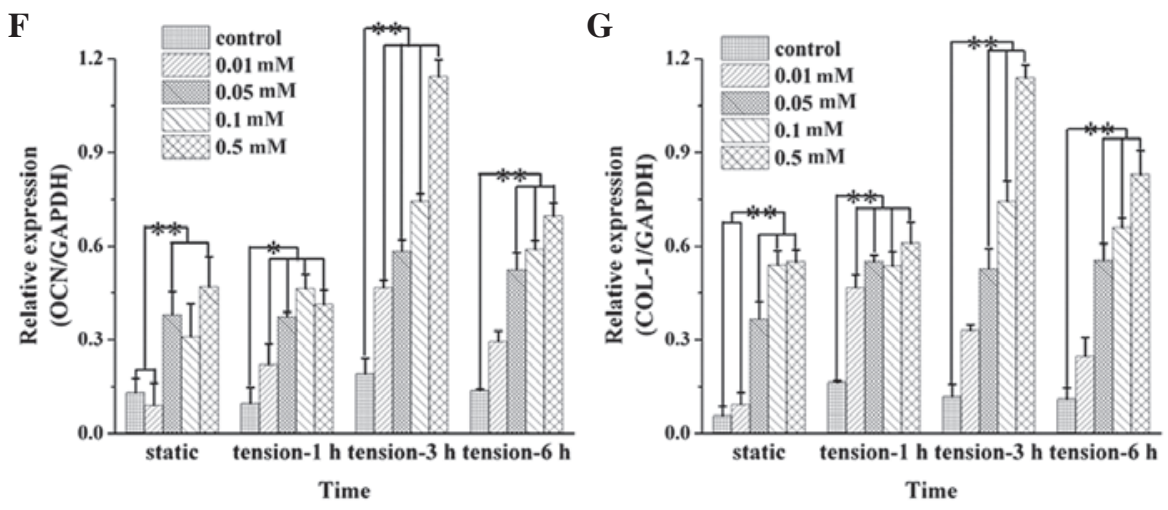

Figure 4. Protein expression of ALP, OCN and COL-1 in hPDLCs following $\mathrm{H}_{2} \mathrm{~S}$ pretreatment. The hPDLCs were treated with $\mathrm{H}_{2} \mathrm{~S}(0-0.5$ mM) and subjected to tension force application for (A) $0,(B) 1,(C) 3$ or (D) $6 \mathrm{~h}$. The protein expression levels of (E) ALP, (F) OCN and (G) COL-1 in the cells were examined using western blot analysis. Prior to application of tension force, the protein expression of ALP and COL- 1 was significantly increased at concentrations of $0.05-0.5 \mathrm{mM}$. The protein expression of OCN was significantly increased at 0.05 and $0.5 \mathrm{mM}$. Following tension force application, $0.01-0.5 \mathrm{mM} \mathrm{H}_{2} \mathrm{~S}$ significantly upregulated the protein expression levels of ALP and OCN in response to 1 and $3 \mathrm{~h}$ tension force, and $0.05-0.5 \mathrm{mM} \mathrm{H}_{2} \mathrm{~S} \mathrm{H}_{2} \mathrm{~S}$ significantly increased the protein expression levels of ALP and OCN induced by $6 \mathrm{~h}$ tension force. Pretreatment with $0.01-0.5 \mathrm{mM} \mathrm{H}_{2} \mathrm{~S}$ significantly upregulated the protein expression of COL-1 following tension force stimulation for $1 \mathrm{~h}$. Treatment with $0.05-0.5 \mathrm{mM} \mathrm{H}_{2} \mathrm{~S}$ significantly increased the protein expression of COL-1 in response to 3 and $6 \mathrm{~h}$ tension force. Protein expression levels of OCN and COL-1 were higher in response to $3 \mathrm{~h}$ tension, compared with 1 and $6 \mathrm{~h}$ tension following incubation with $0.5 \mathrm{mM} \mathrm{H}_{2} \mathrm{~S}$. Data are expressed as the mean \pm standard deviation. ( $\mathrm{P}<0.01$ and ${ }^{* *} \mathrm{P}<0.01$ ). $\mathrm{H}_{2} \mathrm{~S}$, hydrogen sulfide; ALP, alkaline phosphatase; OCN, osteocalcin; COL-1, collagen type I.

ALP is a marker for the calcification and osteoblastic differentiation of PDLCs $(39,40)$. OCN is a vitamin K-dependent $\mathrm{Ca}^{2+}$-binding protein of the bone matrix, which is synthesized by osteoblast-like cells and is considered to be a marker for bone formation $(7,8)$. The collagen molecules in the periodontal ligament are known to respond to mechanical stimuli $(41,42)$. COL-1 is one of the major fibrous elements of the periodontal ligament. It forms solid fibers anchored to the cementum and alveolar bone, and protects the periodontal ligament from tensile stress and masticatory loading $(34,35)$. Therefore, the present study hypothesized that $\mathrm{H}_{2} \mathrm{~S}$ regulates hPDLC differentiation, tissue mineralization and collagen synthesis through modulation of the mRNA and protein levels of ALP, OCN and COL-1.
The data obtained in the present study showed that the $\mathrm{H}_{2} \mathrm{~S}$-induced mRNA and protein expression levels of ALP, OCN and COL-1 were upregulated following tension force application (Fig. 4E). The mechanism underlying this $\mathrm{H}_{2} \mathrm{~S}$-induced expression of ALP, OCN and COL-1 in response to tension-force was not determined in the present study. It has been demonstrated that light mechanical strain induces biological changes in hPDLCs, including the release of various types of adhesion molecules and osteogenic factors, including ALP, OCN and COL-1 (2-4). Studies have shown that static mechanical deformation of PDLCs activates c-Jun and c-Fos, and increases the binding of activator protein-1 to the promoter of ALP, which is a major effector of osteoblastic 
differentiation (43). The gene expression of ALP in hPDLCs as a response to tension stimulation is associated with the intensity of the mechanical force and the culture conditions used (44-47). These findings indicate a potential synergetic effect between $\mathrm{H}_{2} \mathrm{~S}$ and tension force application.

In conclusion, the present study demonstrated that exposure of hPDLCs to a high concentration and prolonged duration with $\mathrm{H}_{2} \mathrm{~S}$ reduced the viability of the hPDLCs. It was observed that $\mathrm{H}_{2} \mathrm{~S}$ significantly upregulated the expression levels of ALP, OCN and COL-1 in the hPDLCs, and pretreatment of the cells with $\mathrm{H}_{2} \mathrm{~S}$ enhanced the expression levels of the proteins induced by tension force stimulation. These results suggested that $\mathrm{H}_{2} \mathrm{~S}$ may be important in remodeling and functional regulation of periodontal tissue. Further investigations are required to elucidate the underlying cellular mechanism.

\section{Acknowledgements}

This study was supported by the National Science Foundation of China (grant no. 81371177).

\section{References}

1. McCulloch CA, Lekic P and McKee MD: Role of physical forces in regulating the form and function of the periodontal ligament. Periodontol 24: 56-72, 2000.

2. Matsuda N, Morita N, Matsuda K and Watanabe M: Proliferation and differentiation of human osteoblastic cells associated with differential activation of MAP kinases in response to epidermal growth factor, hypoxia, and mechanical stress in vitro. Biochem Biophys Res Commun 249: 350-354, 1998.

3. Shimizu N, Ozawa Y, Yamaguchi M, Goseki T, Ohzeki K and Abiko Y: Induction of COX-2 expression by mechanical tension force in human periodontal ligament cells. J Periodontol 69: 670-677, 1998

4. Myokai F, Oyama M, Nishimura F, Ohira T, Yamamoto T, Arai $\mathrm{H}$, Takashiba $\mathrm{S}$ and Murayama Y: Unique genes induced by mechanical stress in periodontal ligament cells. J Periodontal Res 38: 255-261, 2003.

5. Liu M, Dai J, Lin Y, Yang L, Dong H, Li Y, Ding Y and Duan Y: Effect of the cyclic stretch on the expression of osteogenesis genes in human periodontal ligament cells. Gene 491:187-193, 2012.

6. De Bernard B: Glycoproteins in the local mechanism of calcification. Clin Orthop Relat Res: 233-244, 1982.

7. Hauschka PV: Osteocalcin: The vitamin K-dependent Ca2+-binding protein of bone matrix. Haemostasis 16: 258-272, 1986.

8. Neugebauer BM, Moore MA, Broess M, Gerstenfeld LC and Hauschka PV: Characterization of structural sequences in the chicken osteocalcin gene: Expression of osteocalcin by maturing osteoblasts and by hypertrophic chondrocytes in vitro. J Bone Miner Res 10: 157-163, 1995

9. Huang YH, Ohsaki Y and Kurisu K: Distribution of type I and type III collagen in the developing periodontal ligament of mice. Matrix 11: 25-35, 1991.

10. Mariotti A: The extracellular matrix of the periodontium: Dynamic and interactive tissues. Periodontol 2000 3: 39-63, 1993.

11. Beauchamp RO Jr, Bus JS, Popp JA, Boreiko CJ and Andjelkovich DA: A critical-review of the literature on hydrogen-sulfide toxicity. Crit Rev Toxicol 13: 25-97, 1984.

12. Zanardo RC, Brancaleone V, Distrutti E, Fiorucci S, Cirino G and Wallace JL: Hydrogen sulfide is an endogenous modulator of leukocyte-mediated inflammation. FASEB J 20: 2118-2120, 2006.

13. Ma HB, Huang S, Yin XR, Zhang Y and Di ZL: Apoptotic pathway induced by diallyl trisulfide in pancreatic cancer cells. World J Gastroenterol 20: 193-203, 2014.

14. Lee ZW, Teo XY, Tay EY, Tan CH, Hagen T, Moore PK and Deng LW: Utilizing hydrogen sulfide as a novel anti-cancer agent by targeting cancer glycolysis and $\mathrm{pH}$ imbalance. $\mathrm{Br}$ J Pharmacol 171: 4322-4336, 2014
15. Tay AS, Hu LF, Lu M, Wong PT and Bian JS: Hydrogen sulfide protects neurons against hypoxic injury via stimulation of ATP-sensitive potassium channel/protein kinase C/extracellular signal-regulated kinase/heat shock protein 90 pathway. J Neuroscience 167: 277-286, 2010.

16. Baskar R and Bian J: Hydrogen sulfide gas has cell growth regulatory role. Eur J Pharmacol 656: 5-9, 2011.

17. Liao C and Hua Y: Effect of hydrogen sulphide on the expression of osteoprotegerin and receptor activator of NF-kB ligand in human periodontal ligament cells induced by tension-force stimulation. Arch Oral Biol 58: 1784-1790, 2013.

18. Wu Y, Liu F, Zhang X and Shu L: Insulin modulates cytokines expression in human periodontal ligament cells. Arch Oral Biol 59: 1301-1306, 2014

19. Hughes MN, Centelles MN and Moore KP: Making and working with hydrogen sulfide: The chemistry and generation of hydrogen sulfide in vitro and its measurement in vivo: A review. Free Radical Bio Med 47: 1346-1353, 2009.

20. Dong-Xu L, Hong-Ning W, Chun-Ling W, Hong L, Ping S and Xiao Y: Modulus of elasticity of human periodontal ligament by optical measurement and numerical simulation. Angle Orthod 81: 229-236, 2011.

21. Ito M, Suga T, Akiyoshi K, Nukuzuma S, Kon-no M, Umegaki Y, Kohdera U and Ihara T: Detection of measles virus RNA on SYBR green real-time reverse transcription-polymerase chain reaction. Pediatr Int 52: 611-615, 2010.

22. Kimura H, Nagai Y, Umemura K and Kimura Y: Physiological roles of hydrogen sulfide: Synaptic modulation, neuroprotection, and smooth muscle relaxation. Antioxid Redox Signal 7: 795-803, 2005.

23. Piper HM, Meuter K and Schäfer C: Cellular mechanisms of ischemia-reperfusion injury. Ann Thorac Surg 75: S644-S648, 2003.

24. Abe K and Kimura H: The possible role of hydrogen sulfide as an endogenous neuromodulator. J Neurosci 16: 1066-1071, 1996

25. Wei HJ, Li X and Tang XQ: Therapeutic benefits of $\mathrm{H}_{2} \mathrm{~S}$ in Alzheimer's disease. J Clin Neurosci 21: 1665-1669, 2014.

26. Tang XQ, Yang CT, Chen J, Yin WL, Tian SW, Hu B, Feng JQ and $\mathrm{Li}$ YJ: Effect of hydrogen sulphide on beta-amyloid-induced damage in PC12 cells. Clin Exp Pharmacol Physiol 35: 180-186, 2008.

27. Tang XQ, Ren YK, Zhou CF, Yang CT, Gu HF, He JQ, Chen RQ, Zhuang YY, Fang HR and Wang CY: Hydrogen sulfide prevents formaldehyde-induced neurotoxicity to $\mathrm{PC} 12$ cells by attenuation of mitochondrial dysfunction and pro-apoptotic potential. Neurochem Int 61: 16-24, 2012.

28. Eghbal MA, Pennefather PS and O'Brien PJ: $\mathrm{H}_{2} \mathrm{~S}$ cytotoxicity mechanism involves reactive oxygen species formation and mitochondrial depolarization. Toxicology 203: 69-76, 2004.

29. Nyman S, Gottlow J, Karring T and Lindhe J: The regenerative potential of the periodontal ligament. An experimental study in the monkey. J Clin Periodontol 9: 257-265, 1982.

30. Nyman S, Lindhe J, Karring T and Rylander H: New attachment following surgical treatment of human periodontal disease. J Clin Periodontol 9: 290-296, 1982.

31. Nyman S, Gottlow J, Lindhe J, Karring T and Wennstrom J: New attachment formation by guided tissue regeneration. J Periodont Res 22: 252-254, 1987.

32. Somerman MJ, Archer SY, Imm GR and Foster RA: A comparative study of human periodontal ligament cells and gingival fibroblasts in vitro. J Dent Res 67: 66-70, 1988.

33. Liang L, Yu JF, Wang Y, Wang G and Ding Y: Effect of estrogen receptor beta on the osteoblastic differentiation function of human periodontal ligament cells. Arch Oral Biol 53: 553-557, 2008.

34. Kawarizadeh A, Bourauel C, Götz W and Jäger A: Early responses of periodontal ligament cells to mechanical stimulus in vivo. J Dent Res 84: 902-906, 2005.

35. Roberts WE, Mozsary PG and Klingler E: Nuclear size as a cell-kinetic marker for osteoblast differentiation. Am J Anat 165: 373-384, 1982.

36. Wada N, Maeda H, Tanabe K, Tsuda E, Yano K, Nakamuta H and Akamine A: Periodontal ligament cells secrete the factor that inhibits osteoclastic differentiation and function: The factor is osteoprotegerin/osteoclastogenesis inhibitory factor. J Periodontal Res 36: 56-63, 2001.

37. Kobawashi M, Takiguchi T, Suzuki R, Yamaguchi A, Deguchi K, Shionome M, Miyazawa Y, Nishihara T, Nagumo M and Hasegawa K: Recombinant human bone morphogenic protein-2 stimulates osteoblastic differentiation in cells isolated from human periodontal ligament. J Dent Res 78: 1624-1633, 1999. 
38. Verna C, Zaffe D and Siciliani G: Histomorphometric study of bone reactions during orthodontic tooth movement in rats. Bone 24: 371-379, 1999.

39. Groeneveld MC, Everts V and Beertsen W: Alkaline phosphatase activity in the periodontal ligament and gingiva of the rat molar: Its relation to cementum formation. J Dent Res 74: 1374-1381, 1995.

40. Okamoto T, Yatsuyzuka N, Tanaka Y, Kan M, Yamanaka T, Sakamoto A, Takata T, Akagawa Y, Sato GH, Sato JD and Takada K: Growth and differentiation of periodontal ligament-derived cells in serum-free defined culture. In Vitro Cell Dev Biol Anim 33: 302-309, 1997.

41. Von den Hoff JW: Effects of mechanical tension on matrix degradation by human periodontal ligament cells cultured in collagen gels. J Periodont Res 38: 449-457, 2003.

42. Wescott DC, Pinkerton MN, Gaffey BJ, Beggs KT, Milne TJ and Meikle MC: Osteogenic gene expression by human periodontal ligament cells under cyclic tension. J Dent Res 86: 1212-1216, 2007.
43. Peverali FA, Basdra EK and Papavassiliou AG: Stretch-mediated activation of selective MAPK subtypes and potentiation of AP-1 binding in human osteoblastic cells. Mol Med 7: 68-78, 2001.

44. Chiba M and Mitani H: Cytoskeletal changes and the system of regulation of alkaline phosphatase activity in human periodontal ligament cells induced by mechanical stress. Cell Biochem Funct 22: 249-256, 2004.

45. Jacobs C, Grimm S, Ziebart T, Walter C and Wehrbein $H$ Osteogenic differentiation of periodontal fibroblasts is dependent on the strength of mechanical strain. Arch Oral Biol 58: 896-904, 2013.

46. Yamaguchi N, Chiba M and Mitani H: The induction of c-fos mRNA expression by mechanical stress in human periodontal ligament cells. Arch Oral Biol 47: 465-471, 2002.

47. Molina T, Kabsch K, Alonso A, Kohl A, Komposch G and Tomakidi P: Topographic changes of focal adhesion components and modulation of p125FAK activation in stretched human periodontal ligament fibroblasts. J Dent Res 80: 1984-1989, 2001. 